\title{
“The Greek Crisis Ends here Tonight": A Qualitative Study of Labor Market Deregulation in Greece Beyond the "Crisis" Paradigm
}

\author{
Giorgos Poulimenakos \\ Department of Social Anthropology, University of Oslo, Moltke Moes vei 31, \\ Sundts husblokk Ao851, Oslo, Norway
}

Anna Giulia Della Puppa

Department of Social and Cultural Anthropology, Vrije Universiteit

Amsterdam, De Boelelaan 1081, 1081 HV Amsterdam, The Netherlands

\author{
Antonios Alexandridis \\ Department of Social and Cultural Anthropology, Vrije Universiteit \\ Amsterdam, De Boelelaan 1081, 1081 HV Amsterdam, The Netherlands
}

\author{
Dimitris Pavlopoulos \\ Department of Sociology, Vrije Universiteit Amsterdam, \\ De Boelelaan 1081, 1081 HV Amsterdam, The Netherlands
}

\section{Dimitris Dalakoglou}

Department of Social and Cultural Anthropology, Vrije Universiteit Amsterdam, De Boelelaan 1081, 1081 HV Amsterdam, The Netherlands ddu210@vu.nl

\begin{abstract}
The concept of crisis has frequently been used to characterize seismic historical events of the 21st century, and many scholars have interpreted it according to Agamben's elaboration of the state of exception. Following this paradigm, the crisis period in Greece is often perceived as a violent rupture from the previous state of relative stability that spanned the whole social spectrum. We argue, however, that although the idea of exceptions and rupture may be valid for phenomena such as urban policies or social control, it does not apply in the context of the labor market. Attempting
\end{abstract}


to go beyond the idea of crisis as a rupture, in this article we will illustrate how the current crisis instead masks a number of pre-existing phenomena. We do so through qualitative empirical data and analysis of workers' perceptions regarding one of the most emblematic phenomena of the so-called Greek crisis: labor market deregulation.

\section{Keywords}

Greece - crisis - precarity - workers

\section{Introduction}

"The Greek crisis ends here tonight." With this celebratory announcement, made in the summer of 2018, the European Union's Economic Affairs Commissioner, Pierre Moscovici, declared Greece's exit from the crisis and the reinstatement of its economy. However, the return to a state of supposed economic normality has been far from smooth for the majority of Greeks. Since 2010, under the three Economic Adjustment Programs agreed with the EC, the ЕСB and the IMF, Greece has been pummeled by consecutive waves of austerity. The harsh measures they imposed were the prerequisites for the largest bailout loan ever administered to a country and included explicit directives mandating severe reductions in public spending and welfare provision, a full-scale downsizing of the public sector through massive lay-offs and a recruitment embargo, cuts to pensions and public sector wages, and plans for the mass privatization of public assets. ${ }^{1}$

Since the outbreak of the 2008 crisis and the agreement of the first economic adjustment program for Greece in 2010, labor market reform has been a condition of every loan to the Greek government by the EU and the IMF. Indeed, labor market deregulation has been so diligently implemented that it is in fact the only part of the adjustment program to have met all of the initial targets ${ }^{2}$ set for it by the Troika. During the ten years of external economic control, Greek governments agreed to a series of drastic legislative reforms of

1 Sotiris, P. "Greece: The Downsizing of a Country." Greek Left Review (2012), available online at https://greekleftreview.wordpress.com/2012/o9/17/greece-the-downsizing-of-a-country/; Dalakoglou, D. and A. Vradis, eds. Revolt and Crisis in Greece: Between a Present Yet to Pass and a Future Still to Come (Oakland, CA: AK Press, 2011).

2 Targets were either missed entirely or only partially met in the following areas: privatizations, deficit reduction and structural reforms in the public and private sectors. 
labor relations and the increased flexibility of the labor market. Those reforms included deregulation of the collective bargaining system, normalization of flexible and precarious labor, individualization of labor contracts, dismantling of the Labor Inspectorate and reduction of the national minimum wage from $€_{751}$ gross per month to $€_{5} 86$. However, there is no robust evidence that these adjustments contributed to preventing economic downturn and boosting growth, as had been proclaimed. On the contrary, the Greek economy lost $25 \%$ of its GDP, while unemployment soared from 9.5\% in 2009 to $27 \%$ in 2012. Moreover, adjustment policies came at an enormous social cost as poverty and inequality increased dramatically. ${ }^{3}$ Ethnographies of the Greek crisis reveal that from its early stages, the resilience of both society and the economy have been under intense strain. ${ }^{4}$

Generally, the concept of crisis seems apt for describing such seismic reform. For this reason, many scholars have adopted it in order to analyze the phenomena of massive adjustments. ${ }^{5}$ Crisis is often employed in relation to Agamben's state of exception. ${ }^{6}$ Following this line of thought, crises provide an ideological framework of fear and psychological paralysis that facilitates rapid social reengineering in the form of extremely unpopular reconfigurations which, under regular social conditions, would be resisted and opposed. According to this paradigm, the crisis period in Greece constitutes a violent rupture with the previous state of relative normality which emerged during the 'metapolitefsi' period following the collapse of the Regime of the Colonels in 1974. This is exemplified by the social control and repression policies implemented during the years of crisis in order to address what Agamben refers to as tumultus. In order to prevent political institutions from collapsing, the state discards normal legal procedures and fast-tracked laws rapidly become the new normal. In this sense, crisis and the consequent establishment of a long/ permanent state of exception is a rupture. The 2010 anti-terrorism law criminalizing the use of specific protest apparel including hoodies (the so-called "koukoulonomos") was an "exceptional" use of legislative and executive force, for instance. Indeed, although similar legislations are not at all new during

3 Karamessini, M. "The Greek Social Model: Towards a Deregulated Labour Market and Residual Social Protection." In The European Social Model in Crisis: Is Europe Losing Its Soul?, ed. D. Vaughan-Whitehead (Geneva/Cheltenham: ILO, 2015), 230-288; Papatheodorou, C., "Economic Crisis, Poverty and Deprivation in Greece: The Impact of Neoliberal Remedies." In Greek Capitalism in Crisis, ed. S. Mavroudeas (London: Routledge, 2020), 205-221.

4 Dalakoglou, D. and G. Agelopoulos, eds. Critical Times in Greece: Anthropological Engagements with the Crisis (London: Routledge, 2018).

5 Klein, N. The Shock Doctrine (London: Macmillan, 2008).

6 Agamben, G. State of Exception (Chichago, IL: University of Chicago Press, 2005). 
the "metapolitefsi", what seems interesting here is the fact that what has been criminalized was not, in fact, merely a political stance, but mostly the regular use of a specific apparel. The proverbial "black hoodie" has been considered guilty of enacting a performative lifestyle, not necessarily connected with a manifestation of an openly political stance -and especially in the urban context-, in the need of been repressed by one of "a continuous series of small coups d'état" in Agamben's terms. ${ }^{7}$

Nevertheless, many authors are discussing lately either or not the ideological framework of the State of Exception suits the analysis of the Greek crisis. ${ }^{8}$

For what concerns the qualitative data we shall present here shows, in the case of labor market deregulation in Greece, the crisis does not constitute a rupture with the previous paradigm so much as an intensification of existing processes. ${ }^{9}$

\section{The Research Sites}

Our research consisted of qualitative enquiry in 4 separate locations in Greece. The authors' diverse positionality in the field and their research interests led to the multi-sited approach. Moreover, the particular research sites are indicative of different economies within Greece, a variety that reveals different dispositions towards labor by the individuals. From the class polarized environment of the Athens metropolis, to Paros as the representative of seasonal, touristic (para)economy, Lesvos as the center of a newly emerged employment scene due to the refugee situation, and Sparta, a traditionally middle-class small town with high pluriactivity, the crisis is a concept that only gains meaning in relation to the people's biographies and affiliations within particular economic environments. The researchers conducted interviews where they were already working, so although outside the remit of their specific ethnographic projects, interviews were carried out in locations familiar to them. As the project's aim was to confute the perception of the crisis as a rupture in a "normal" economic

7 Agamben, G. "For a Theory of Destituent Power." Chronos (February 2014), available online at https://criticallegalthinking.com/2014/02/05/theory-destituent-power/.

8 Rakopoulos, T. "The Crisis Seen from below, within, and against: From Solidarity Economy to Food Distribution Cooperatives in Greece." Dialectical Anthropology 38 (2) (2014), 189-207, https://doi.org/10.1007/s10624-014-9342-5; Athanasiou, O., P.K. Goldberg and N. Pavcnik. "Trade Reforms and Wage Inequality in Colombia." Journal of Development Economics 74 (2) (2004), 331-366; Douzinas, C. Philosophy and Resistance in the Crisis: Greece and the Future of Europe (London: Polity Press, 2013).

9 Dalakoglou, D. “The Crisis before 'The Crisis': Violence and Urban Neoliberalization in Athens 1." Social Justice 39 (1) (2013), 24-42. 
flow, diverse sites with their local particularities provided a wide variety of labor and social regimes to test the hypothesis of non-rupture. Specifically, this project aims to show that the "crisis" is not perceived as such on the basis of objective, static economic facts. On the contrary, if a subject is to perceive the condition as a "crisis" or a "rupture" or not, is based on particular sociocultural factors as the class position from which the subject is perceiving his/ her reality, the ties with the state and local perceptions of labor as morality. Therefore, a multi-sited ethnography was crucial as to reveal different stances on the so-called crisis. Between 2017 and 2018 we conducted interviews with more than 50 workers, most of them on repeated occasions. All interviewees were between 25 and 45 years of age and the majority had experience of working both before and after the crisis. We interviewed both people whose parents were born in Greece and people of migratory background. The sites are as follows:

- Athens - capital city of Greece and a European metropolis that is home to 3.75 million people. ${ }^{10}$

- Paros - one of the largest islands of the Cyclades in the Aegean Sea. It has about 12 ooo registered residents and is typical in depending almost entirely on tourism. Between May and July 2019 alone, 334291 tourists visited the island.

- Lesvos - a border-island located in the Northeastern Aegean with 86 ooo inhabitants recorded in the 2011 census. Due to its close proximity to Turkey, Lesvos has been central in the refugee question since the summer of 2015. From 2015 until today, it has been the European arrival point for more than 600 ooo refugees, necessitating significant funds from the EU. Various NGO s have set themselves up on the island, thereby changing its employment landscape.

- Sparta-a provincial town as well as the administrative capital of Laconia prefecture in southern Greece. According to the 2011 census, it has roughly 16239 inhabitants. ${ }^{11}$ Its economic structure is comprised of small-scale retailers, agriculture and public services.

\section{The Greek Capitalist Model and the Crisis before the "Crisis"}

Research on the pre-crisis era (1980-2008) in the fields of economics, sociology and demography indicates an enduringly idiosyncratic labor market with

\footnotetext{
10 Source: Hellenic Statistical Authority (2014).

11 Source: http://www.statistics.gr/el/statistics/-/publication/SAMo3/.
} 
intrinsic elements of informality and deregulated labor relations for specific social groups. ${ }^{12}$ Prior to the crisis, Greece had the highest self-employment and business ownership rates in the EU, with the vast majority of businesses consisting of small-scale family stores sustained by unpaid family labor and/ or small numbers of undeclared or semi-declared employees..$^{13}$ During this period, both labor inspection institutions and, consequently, the enforcement of labor law and protection mechanisms, were very weak (Karamesini, 2015). Public servants, by contrast, enjoyed a highly protected working environment with strong trade unions. ${ }^{14}$ This was due to the Greek state's strategy of mass recruitment into the public sector, in a bid to incorporate (and therefore neutralize) a significant portion of the population that had been radicalized in the period following the civil war. This dualistic nature of the historical development of labor relations in Greece laid the ground for a confrontational and syndicalist habitus ${ }^{15}$ among the industrial working-class, as well as amongst public servants. Contrastingly, amongst the unskilled or technically skilled working-class scattered around small family businesses, it has forged a social group that is unconnected, unorganized, and in most cases, lacking both a formal labor contract and representation.

Between the 1990s and the first half of the 200os, at the height of the so-called "golden era" of Greek development, ${ }^{16}$ a new social group, undetected by quantitative datasets, came from the North to join Greece's pre-crisis precariats. ${ }^{17}$ This was a period of sweeping change globally, during which existing

12 Karamessini, "The Greek Social Model: Towards a Deregulated Labour Market and Residual Social Protection"; Sakellaropoulos, S., ed. "Change in Social Stratification in the Greece of Crisis (2009-2017)." In Greece's (Un) Competitive Capitalism and the Economic Crisis (London: Palgrave Macmillan, 2019), 123-138.

13 Katsios, S. "The Shadow Economy and Corruption in Greece." South-Eastern Europe Journal of Economics 4 (1) (2006), 61-80; Tsoukalas, K. The State, Society and Labor in Post-War Greece (in Greek) (Athens: Themelio, 1985); Petmesidou, M. and A.M. Guillén. "Southern-Style' National Health Services? Recent Reforms and Trends in Spain and Greece." Social Policy \& Administration 42 (2) (2008), 106-124.

14 Tsoukalas, The State, Society and Labor in Post-War Greece (in Greek); Papageorgiou, V. "Discourses and Practices of Resistance to the Neoliberal Domination (in Greek)" (2014),

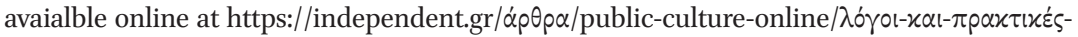

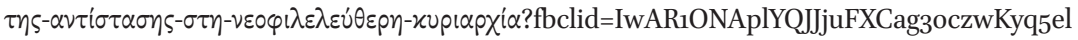
g5xKuwUOZv9AqgtLYPKcxKZuS812Q.

15 Bourdieu, P. Outline of a Theory of Practice, Cambridge Studies in Social Anthropology volume 16. Series ed. J. Goody (Cambridge University Press, 1977).

16 Kaplanis, Y. "An Economy That Excludes the Many and an 'Accidental' Revolt." In Revolt and Crisis in Greece, eds. Vradis, A. and D. Dalakoglou (Oakland, CA: AK Press, 2011), 215228; Dalakoglou, "The Crisis before 'The Crisis': Violence and Urban Neoliberalization in Athens 1."

Standing, G. The Precariat. The New Dangerous Class (London: Bloomsbury Academic, 2011). 
socialism collapsed and more than 600 ooo migrants from ex-socialist Balkan countries crossed Greece's borders. The migrants who arrived during this period, mostly undocumented or semi-documented, survived under extremely precarious conditions. They were exploited as cheap, undeclared labor, and often worked under hazardous conditions. It was the labor of these migrants which enabled the infrastructural boom culminating in the construction fever building to the 2004 Athens Olympics. ${ }^{18}$

While one stream of the Balkan migratory flow scraped a living in Athens' hostile metropolitan environment by building the Greek capital's "European face", another contingent moved to the countryside to evade document checks by Greek authorities. The cheap labor migrants provided to small-scale employers also contributed significantly to rural Greece's modernization and blending into the EU. According to the Anthropologist Christopher Lawrence, the social and cultural transformation of the Greek countryside could only be achieved through the creation of a vulnerable, marginalized class of cheap migrant workers with no rights, who helped make Greek agricultural products become competitive on the global market. ${ }^{19}$ Their labor enabled rural Greece's conversion from a place defined by a system of poor domestic production marked by a conservative, familial culture to a relatively prosperous agricultural market in which social liberalization also transformed the position of women and children.

As should be evident from our discussion of these diverse social groups who have been experiencing labor precarity and socioeconomic uncertainty since well before the so-called crisis era, the labor of workers who are beyond the purview of both legislation and a broader notion of normality is something that has been inherent to the development of capitalism in Greece. As we now show in our analysis, the state of being in "crisis" presupposes a particular habitus of having previously lived in relative security, as well as certain physical and mental predispositions that allow individuals to experience the distinction between crisis and normality.

\section{Informal Labor: "Same Old, Same Old"}

According to our research, informal labor was the most common form of labor for people living in all of our field sites, both before and during the crisis. The

18 Dalakoglou, D. The Road: An Ethnography of (Im)Mobility, Space and Cross-Border Infrastructures in the Balkans (Manchester: Manchester University Press, 2017); Dalakoglou, "The Crisis before "The Crisis': Violence and Urban Neoliberalization in Athens 1."

19 Lawrence, C.M. Blood and Oranges: Immigrant Labor and European Markets in Rural Greece (New York, NY: Berghahn Books, 2011). 
exception to this pattern is the group of NGO workers in Lesvos who, for the first time in their lives, are now formally employed. It is striking to note that those interviewees, however, described their working conditions as "unreal" or "European". Our sample consisted of skilled laborers and university graduates who are currently working or have worked outside their field of expertise, and unskilled workers.

Our first interviewee is Menipos, a 31-year-old who has lived his whole life in his town of origin. He graduated from a technical high school but did not get into university, so he has been working in various jobs since he was 18. As his town lacks any heavy- or light-industrial sector employment options, those who do not possess agricultural land are confined to the retail and service sectors: the plethora of cafes, mini-markets, gambling stores, fast-food outlets, telecommunications stores etc. In every job, both before and during the crisis, Menipos was paid "under the counter". He has therefore never had insurance, nor has he accumulated a single pension credit. As he told us:

I've been working since 2004 and I still don't know what it's like to be legally employed, you know with extra wages at Christmas and all that. I'm 31 years old now and I don't have a single ensimo. ${ }^{20}$ What am I going to do? For all these years, I've been getting cash in hand from the bosses as if we were pals. That's if I get paid at all. I remember back in $2005 \mathrm{I}$ was working in a hotel, and the guy just refused to give me the money I'd worked for. I had to put pressure on him for three months and to threaten him with legal action to get the money. Of course, after that I left. When you're unregistered you rely on the boss' good will. In another job I had in around 2007 in a fast food outlet, the boss wanted me to work for $15^{-16}$ hours to get the minimum wage. What can you do? The only thing you can do is quit.

Menipos now works in a store. When asked whether he sees any changes nowadays, he said wages were slightly higher before the crisis, but otherwise no. Employers only care for quick profits.

Melina is 28 years old. She returned to her hometown after obtaining her degree in social work. As a high school student she had worked as a waitress during weekends and vacations. Since coming home, she has been working in a bar again. From Melina's perspective, labor relations have not deteriorated

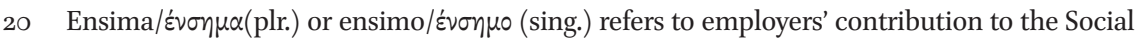
Insurance Department to cover the employee's insurance. A worker needs to accumulate a specific number of ensima in order to retire and qualify for a pension. 
during the crisis and may even have improved. She told us that just like before, employees like her mostly work in the black, but since the crisis, labor inspections are slightly stricter.

Cafeterias and bars are workplaces in which cash-in-hand employment is the norm. Like Melina, Kostas, a barista in a cooperative café-bar in Athens failed to see any difference in working conditions in his sector:

I think the worst years were from 2012 to 2014 . We certainly had big economic problems in the country before, but there was a lot of black market labor and there was no social turmoil. You just had a whole country working, most of them "underground", and nobody did anything about it, as usual... Now we still have more or less the same situation. We might get shocked by the unemployment numbers we hear about, but most people are working and working off the books.

Another point that was raised by interviewees in Paros was that actual working hours during the summer season never correspond with what is written on the books, and people are forced to work overtime without exta wages. The casualness of these agreements enables employers to exercise extreme levels of labor control over workers. Lida works as a shop assistant on Paros island. She used to work for the same amount of money, $€ 1200$ per month, as a marine biologist for a research center in Athens for far fewer hours. In the shop, many hours are undeclared and "an employer will laugh at you if you ask for a day off in the summer season." The practice of paying in black is a response to the implementation of the Memorandum's fiscal plan for tackling tax evasion. Almost every worker we interviewed agreed that tax inspections are getting stricter than before the crisis, and this was a widespread rumor on the island in the summers during which we conducted fieldwork. As Katerina, an interior designer told us,

It's only in winter that I've worked totally off the books, because in the summer there are many inspections and employers don't want to face the risk of getting caught. But I always prefer not to work in the black, because I want my (tax and insurance) contributions and benefits to be in order.

Working for an international NGO with a formal labor agreement in Lesvos was an unprecedented experience for our interviewees there. As graduates in the social sciences, the majority of them had worked in a variety of jobs before the refugee crisis hit Greece. In many cases, informality in the labor market 
seemed completely normal to these workers. Andreas, who used to work as a delivery driver, felt that the economic crisis had not changed anything. In his job employers only declared 3 hours for every 10-12-hour shift, and drivers were unable to accrue credits or insurance. If they wanted a job, they had to accept this standard exploitation. When we asked him whether he was referring to the pre-crisis era or the present, he told us it was the same now as before; that people everywhere would always try to make as much as possible with the least effort.

In addition, within the current flexible labor environment, workers in this informal economy do not have clear job descriptions. Nasos talks about his experience in a pizzeria during the pre-crisis era:

I was supposed to be doing deliveries, but really, I did a bit of everythingI helped make the pizzas, clean the tables, wait on people ... the more you do the better you are, "a good boy". There was no contract, and so this would last as long as he'd let me keep the job, or as long as I'd stay.

As the labor experiences described in the previous section demonstrate, working people in Greece, especially the younger generation, have faced precarious conditions and grim futures since before the crisis. A further aspect of these precarious conditions is the frequent change of job our interviewees reported, particularly those from Sparta; only one had held the same job since she started working while the majority changed jobs every few months.

Researchers like Tsoukalas ${ }^{21}$ view the recent increase in flexible patterns of employment, the zero-hours contract and the freedom to jump between jobs as an emancipatory development for the working-classes. He argues that since the 19th century, capitalism's domination has been based purely on its ability to affect a total absorption of workers' time in such a way that it gave them no other option than to sell their labor. For Tsoukalas, the new forms of flexible labor together with the subsidized income through state allowances (or forms of universal income) give workers the ability to distance themselves from wage labor and pursue different ways of earning a living so as to diversify their skills and their subsequent ability to negotiate better terms of employment.

Our research findings do not support this theory. The majority of those we interviewed did not appear to be jumping from job to job out of choice,

Tsoukalas, The State, Society and Labor in Post-War Greece (in Greek). 
but instead, as their stories testify, because of arbitrary actions taken by their employers. It is however true that workers demonstrate signs of pluriactivity ${ }^{22}$ that is, they are earning money through activities that are parallel to their waged job, mostly in the informal economy. Nevertheless, such parallel activities do not represent a conscious step away from wage labor or a strategy to better negotiate with employers, but are instead basic survival strategies.

More recent, empirical studies such as Koumenta and Williams' research on zero-hours contracts in the $\mathrm{UK}^{23}$ associate the precarious forms of employment with low wages and underemployment that are more likely to bind the workers more to wage labor through the pursuit of more than one wage job than empowering them to negotiate better working conditions. As Koumenta and Williams illustrate, the regime of zero-hours contract is more susceptible to working places that traditionally lack union presence.

Kalliope, a 3o-year-old graduate in social theology, could not find a job in her sector, so in 2010 she decided to return to her hometown and take any job she could find. She described the highly exploitative conditions in several jobs she moved through in quick succession-working several shifts in a row in the black, sometimes for 18 hours straight; not getting paid several months running as the boss told her he was broke and having to leave with nothing; signing for bonuses she never received and finally surviving by working several part-time undocumented jobs, "at the same time I do baby-sitting, informally, here and there. I can barely make ends meet with these two jobs but what can you do?"

Pavlos is 36 years old and lives in Athens. He holds a postgraduate degree in chemistry but never managed to find a job in his field. When we spoke to him, he was a temporary worker in the municipality of Athens. His job is part of the Job Centre's (OAED) EU-funded program for rehabilitating unemployed workers. Although those participating in this program actually work in the public sector, they are considered "beneficiaries" and therefore fall under the remit of private law. Contracts are 8 months long and wages are half those of permanent staff:

I'm working in the program now. They took me on because of my degree but that doesn't mean I do chemistry there, mostly I coordinate the movements of the garbage trucks but at least I'm using my degree (laughs). The money is shit. I get $€ 495$ where others in the same job get $€$ €ooo or more, I suppose it's our generation's curse. In the afternoons, I

22 Ibid.

23 Koumenta, M. and M. Williams. "An Anatomy of Zero-Hour Contracts in the UK." Industrial Relations Journal 5o (1) (2019), 20-40. 
do another job-I write university theses for people who are either not capable of doing it or just can't be bothered. It's ridiculous, they think that if they get their degree then everything will be okay, but if you don't know the thing you're studying, how can you do anything with it? On the other hand, if you look at my case, then you realize that you only need the formal qualification. Anyway, the money's good, though it consumes a lot of your time. You can get $€_{1000}$ to $€_{15}$ oo for a thesis every two months. I know it's illegal and maybe it's not right, but you add that to the $€_{495}$ from the program and then you have a real wage."

The experiences discussed above, and the fact that Pavlos used the label "real wage", show that pluriactivity today does not imply a move away from wage labor, nor is it a choice, as Tsoukalas argues. The cases show that pluriactivity in the informal economy and informal wage labor are part of the same process, and they now constitute the only survival strategy available to most young people.

One of the major repercussions of the "shock" treatment ${ }^{24}$ Greece was subjected to during the financial crisis was the devaluation and demonization of the public sector. ${ }^{25}$ The country's image as run by an outmoded, populist and bureaucratic state-with supposedly vast numbers of public employees and untapped reserves of public assets - was conjured up, and then blamed for the debt. This discourse helped justify a freeze in public sector recruitment (by imposing the rule of 1 hire per 10 retirements), which was rolled out irrespective of the operational needs of public administration or candidates' qualifications.

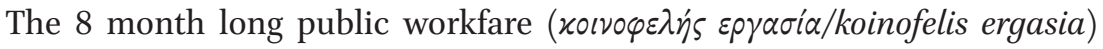
organized in municipalities by the OAED, together with other similar EU-subsidized programs, constitute the only way in which young people today can get experience working in the public sector. However, as Pavlos' case shows, despite the fact that they are performing core roles, these young people's labor conditions differ from those of permanent staff.

24 Klein, The Shock Doctrine.

25 Giannis Mavris, "The Rise of Conservatism: Political Ideologies in Greece after the Memorandum" (in Greek) (2007), available online at https:/www.mavris.gr/4943/ political-ideology/. 
Melina, who we met above, is now working as a social worker in a municipality near her town through one of these programs. Her description of the experience highlights these differences:

If you think about it too much you'll go crazy. The municipality didn't even have a social worker before, and now I'm covering the whole region. That means I have a huge caseload, and yet for some reason I get half or even a third of the money that permanent staff get. But it's not just the money. You know if you read our contract you won't find the word "employee" in it. We are referred to as "beneficiaries"—like they're doing us a favor and that's why we're working for nothing. I remember in the first month I was here there was a national strike organized by the public servants' union. We were told that we were not allowed to go on strike because we weren't officially employed there! Screw that! I went on strike anyway. And then there's also the way some of the permanent staff look at you. Like you're inferior, like you don't matter. In a way that's true, because I'll be out of here soon.

Alexis, who lives in Lesvos, describes his first experience as a psychologist for the Ministry of Public Order as part of the EU-subsidized ESPA ${ }^{26}$ project. Even though he had a high-status job and his position was an important one, he was still reliant on the support of his social network:

In the first job, we signed a normal contract. We had a problem with the leave conditions though - they told us that because the contract was for 5 months we weren't entitled to any leave, that leave entitlements were only for contracts of over 8 months or 1 year, I can't remember exactly. The payment was also bad, even though it was through EsPA, payments were always late. I think, because we're talking about 2012, they were delayed by at least 3 months, maybe more. The next job I had in the ministry was also delayed [the payment]. Not as much, but still plenty. The problem was that you needed to pay your social insurance fee to the pension and social security organization (TEVE), ${ }^{27}$ and you had to do that first in order for the next payment to be authorized, so if you didn't have any savings, you had to borrow money to pay TEVE. So it was a vicious circle. This was going on in all the projects run by the Ministry of Public Order that I worked in as a psychologist, in deportation centers. The worst problem

26 European Structural and Investment Funds of the European Union.

27 TEVE is the social insurance agency for freelancers. 
we had was from the end of 2014 to mid-2015, then pay was delayed for 5 months $[\ldots]$

Eleonora, a 35-year-old journalist, decided to return to her village during the crisis. She is also working in a municipality, but not as part of the OAED's programs. Instead she has been hired under the "special mayoral advisor" employment regime. The Greek constitution permits members of the Parliament as well as mayors to hire a number of "advisors" of their choice, outside of standard recruitment protocols for public servants. When the politician's term ends, the special advisors are discharged, unless their successor wishes to keep them on. In the countryside in particular, these positions are usually distributed on the basis of patronage obligations. In this case, Eleonora was given the position because her mother is well-known in her village and has a very large social network, which translates into a significant pool of votes.

The day after we interviewed her, Eleonora told us the following story:

I'm in a damn difficult position today. A guy who worked for the municipality last month, in the black, cutting the grass or something, called me today. He said that the mayor refused to give him the money he was due. After he pressed him, the mayor told the guy to call me and ask me to give him my salary for this month! Do you understand what that means? I have to give my salary to some guy and work this month for free. Of course, I gave the mayor a call. He told me that I got this position thanks to him and so I had better obey. What should I do? Of course, my self-respect tells me to tell him to go fuck himself and quit, but where else am I going to work?

Finally, we also found evidence of informal labor in Lesvos. Menelaos, who was working informally for the municipality as a photographer told us:

It was an acquaintance of mine who works at a photography studio who mentioned the job to me. He told me that the municipality was opening up a position because they wanted photographers from all the photography studios in Mytilene to go to the camps ... and take pictures of the refugees for their documents. Naturally these pictures were taken for money, it was $€ 10$ for 4 of them. So we worked inside the camp, one of the first to be built, and we took pictures and sold them. There was no contract with me, only with my boss, and the boss simply had his team and paid them ... No, they didn't have contracts, they were working because the money was good, $€_{5}$ o for 4 hours. So I thought, here we go! This is it! And that was my first experience working on the refugee question. 
As these stories make evident, Greece's economy is defined less and less by a dichotomy between a protected public sector and a precarious private sector. Nowadays, many of those in the public sector actually work in a variety of ambiguous and hybrid public/private positions. In addition, the fear, precarity and humiliation that characterize labor relations in the private sector have today colonized the public sector as well.

\section{$7 \quad$ Precarity Tolerated? An Anatomy of Workers' Consciousness}

Any ethnographic study of labor market conditions should incorporate not only an exploration of the objective markers of deregulation, but also of workers' perceptions of labor and labor relations. The next phase of our research focused on investigating how the workers in our sample viewed their working conditions, both socially and politically. We observed a general aversion towards politics, and either a feeling of impotence with regards to changing their situation, or an unwillingness to attempt to do so.

How is it that people come to tolerate such working conditions? This question opens up the problematic of social and political compliance and passivity - as it has been cast in anthropology. Understanding of this issue has, we believe, been obscured by the over-studied notion of "resistance". ${ }^{28}$ Workers' consciousness, we show, is shaped by various factors - most notably, local categories of social status, cultural specificities, networks of social relations and discourses about the crisis.

Melina talked to us about the poor conditions she and her colleagues tolerated working in bars and cafes:

Look, this is a small town and the businesses here are small-scale. That means that you know your boss personally, you would probably have been friends before he opened the bar. They make you think we're all a big family. And because of these personal relations, people are too embarrassed

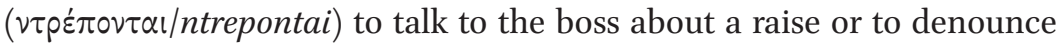
them. Not only are they embarrassed, but many of them even think it's

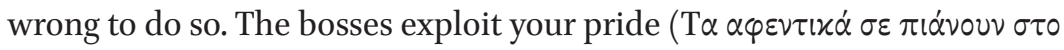

28 Astrinaki, R. "Dis-Assembling the Social: The Politics of Affective Violence in Memorandum Greece." In Violent Reverberations, eds. V. Broch-Due and B.E. Bertelsen (Cham: Palgrave Macmillan, 2016), 143-171. 
$\varphi(\lambda o ́ \tau t \mu o / s e ~ p i a n o u n ~ s t o ~ f i l o t i m o) .{ }^{29}$ Even I, who am pro trade-union and a leftist, sometimes I find myself too embarrassed to make a complaint.

This quote reveals how personal relations influence capital-labor relations in small towns and small businesses. These business owners generally come from the same social background as their workers, possess the same habitus ${ }^{30}$ and relate to them personally. The resulting familiarity in the workplace functions as an ideology that deters workers from claiming their rights.

When we asked Ioanna, a 22-year-old waitress from Athens, for her opinion about trade unionism, we got the same sense of moralism, "I'm not interested in all that ... it's just not in my character. I'm an easy-going person, I couldn't raise my voice or anything like that."

Working in bars and cafes also conferred a measure of social status on young employees. Nefeli, a 22-year-old doing an internship at a computer education center, said about her friends:

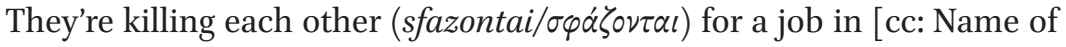
posh cafe in the town]. It's very important to people to work there you know. If you're a guy and you work there, then you're definitely going to have a good girlfriend. Do you think they care if they're exploited or given shit money? They just don't.

Although an in-depth exploration of the question of consciousness is outside the scope of our research, it is clear we need to move beyond a purely economistic approach if we are to understand the subjective meaning of workers' exploitation. As Daniel Knight notes, ${ }^{31}$ local signifiers of social status affect how conditions of crisis, prosperity and precarity are experienced.

Regarding the crisis, the majority of respondents considered it a product of the corrupt nature of politics. Only one articulated a specific argument on the nature of the crisis, while some even argued that the crisis was a purely psychological phenomenon.

As Nefeli puts it:

The crisis is in our heads. If you're always saying to yourself "oh my god I don't have money" and so on, then you'll be in crisis. But if you stay calm

29 Can be loosely translated as referring to the subjective moral obligation to show respect to someone.

30 Bourdieu, Outline of a Theory of Practice.

31 Knight, D.-M. "Crisis and Prosperity: Status, Accountability and Time in Central Greece" (Durham: Durham University, 2011). 
and organize your life properly, you're not going to have any problems. We should turn off our Tv s. They're scaring people. Come on, what crisis? Things are not so bad.

By contrast, Alekos, who works in a bakery, believes that the crisis is real and that it's the people's fault, "Look, the politicians are what they are but it's our fault too. Everyone wanted to be a doctor or a lawyer in Greece. We wanted the sweet life. It was considered shameful to be a farmer or whatever. So then how did we think we were going to survive?"

Respondents' accounts revealed a conflicted state in which precarity and material deprivation coexisted with passivity or acceptance of the existing reality.

\section{$8 \quad$ Conclusions}

Our findings on the social cost of deregulation are not confined to Greece. Indeed, there is a field of research that provides strong empirical evidence that deregulation policies weaken welfare state provisions. ${ }^{32}$ The anthropological preoccupation with economic relations among people has focused, from the outset, on critiquing the universal validity of the notion of homo economicus. Homo economicus, or economic man, describes a particular tendency of human nature that inclines towards the maximization of utility and the rational evaluation of people's activities. According to this line of thought, economic interactions among humans make up a discrete and abstract field of relations in which human beings act like mathematical entities, in isolation from their other social characteristics and identities. The origins of this anthropological type, which is credited with providing the ideological foundations of the newly emerging capitalist economy, can be traced back to the formation of classic political economy. ${ }^{33}$

32 Lewis, P. "(How) Do Flexible Labour Markets Really Work? The Role of Profitability in Influencing Unemployment." Cambridge Journal of Economics 33 (1) (2009), 51-77; Giovannoni, O. "Functional Distribution of Income, Inequality and the Incidence of Poverty: Stylized Facts and the Role of Macroeconomic Policy," UTIP Working Papers (Austin, TX: University of Texas Press, 2010); Jaumotte F. and C. Osorio Buitron, "Inequality and Labor Market Institutions" (Washington, DC: IMF, 2015).

33 Mill, J.S. "On the Definition of Political Economy, and of the Method of Investigation. " In Essays on Some Unsettled Questions of Political Economy, volume 7, ed. J.S. Mill (London: Routledge/Thoemmes, 1844). 
The seminal work of Mauss ${ }^{34}$ dealt a heavy blow to the homo economicus conception of human nature. His analysis of economic behavior and practices in various so-called non-Western societies revealed that instead of maximizing profit, people strove, through a well-established system of gift exchange, to enhance social relations. For Mauss, these peoples' first priority was not to accumulate wealth, but rather, by giving it away in the form of gifts, to secure alliances, social solidarity and moral superiority.

The Maussian paradigm has undergirded interest among social scientists in the social and moral aspects of people's economic behavior. According to E.P. Thompson's moral-economy interpretation of the 18 th century food riots in England, the uprising was not a rational, automatic response by the people to hunger and poverty. Instead, what led people to collective action was the transgression, by the market, of deeply rooted moral values concerning food prices and the place of food in the realm of social reproduction. Since Thompson's time, the term moral economy has mainly come to signify informal economic practices that are alternative or in opposition to the logic of the commodity and the market, and which are based on specific social and cultural values. ${ }^{35}$

However, as some scholars have recently noted, ${ }^{36}$ conceptualizations of the moral aspects of economic relations should not be limited by the tendency of researchers to record practices that defy market logic and capitalism in general. Because all economic activities contain moral dimensions, we should trace morality as a motive not only for anti-market action, but also for those activities that promote compliance and the normalization of economic relations, even where these may be unjust or unacceptable.

Dimitra Kofti's research ${ }^{37}$ sets out to apply this broader conception of morality in economic activity to the analysis of flexible forms of labor in a Bulgarian factory in the post-socialist era. Kofti argues that the apparent tolerance workers show for low-wage and flexible regimes of labor is formulated within complex and intertwined moral values that relate to their lives both inside and outside the factory. For example, familial relations between workers

34 Mauss, M. The Gift: The Form and Reason for Exchange in Archaic Societies, 2nd edn. (Chicago, IL: Routledge, 2001).

35 Palomera, J. and T. Vetta. "Moral Economy: Rethinking a Radical Concept." Anthropological Theory 16 (4) (2016), 413-432.

36 Ibid; Narotzky, S. "The Payoff of Love and the Traffic of Favours." In Flexible Capitalism, ed. J. Kjaerulff (Oxford: Berghahn, 2018), 173-206; Kofti, D. "Moral Economy of Flexible Production: Fabricating Precarity between the Conveyor Belt and the Household." Anthropological Theory 16 (4) (2016), 433-453.

37 Kofti, "Moral Economy of Flexible Production: Fabricating Precarity between the Conveyor Belt and the Household." 
who are also married to each other may have the effect of silencing the gender pay gap thanks to a sense of household solidarity.

Our research also indicates that people do not necessarily evaluate their working conditions in terms of objective exploitation, but rather through a complex set of ideas about morality and social status that extend beyond the workplace. As in the case of the posh provincial cafe, precarious working conditions become less important where the job in question offers a status that increases one's prospects of an intimate relationship. Or, as Melina's case signals, even the left-wing persuasions and trade-union history of an employee can be compromised by the high value people attribute to informal relations. In our examples, friendship, the informal relation par excellence, merges with the informality of labor to produce a situation in which keeping labor informal comes to be understood as a moral obligation for workers. In his book Bullshit Jobs: A Theory ${ }^{38}$ David Graeber supports that it is the dominant Puritan-capitalist work ethic that makes work a determinant of self-worth for the workers which is independent to the economic or productivity outcomes of their labor.

\subsection{Crisis as (Non)rupture}

Discourses often appear in the Greek media or among political elites that orbit around the rhetoric of "rupture" and the sudden deregulation that resulted in the loss of established workers' rights. These discourses are based on statistical research and legislation that was passed during the crisis years. This project, by contrast, offers an ethnographically grounded critique of the inherent abstractions that these perceptions of the crisis entail. As anthropologist Henrik Vigh argues, ${ }^{39}$ any talk of crisis as an episodic, sudden event that disrupts a previously ordered and sustainable environment is always the expression of a biased class, gender or race position. This is so because in every social formation, and across the global system's divisions, there exist structurally marginalized social groups - the poor, sans papier immigrants and so on - who are always "in crisis". It is precisely their position in the system of exploitation that creates the conditions for the normality that members of the more privileged social strata experience during times of non-crisis. ${ }^{40}$

$3^{8}$ Graeber, D. Bullshit Jobs: A Theory (New York, NY: Simon \& Schuster, 2018).

39 Vigh, H. "Crisis and Chronicity: Anthropological Perspectives on Continuous Conflict and Decline." Ethnos 73 (1) (2008), 5-24.

40 Dalakoglou, "The Crisis before 'The Crisis': Violence and Urban Neoliberalization in Athens 1." 
A unique feature of deregulation in Greece is that, since 2010, these policies have been implemented at an extremely accelerated pace and in their most drastic form, thereby constituting an innovation in the pace of change in the EU's Common Labor Market which, until then, had been evolving gradually over decades. The Greek case might set a precedent for how reforms will be implemented elsewhere. Illustrative of this possibility is the January 2017 warning by the UK's largest equity fund owner that Brexit may result in a $30 \%$ decrease in wages. ${ }^{41}$

Greece offers an ideal case study for investigating the above- mentioned phenomena. Since its accession to the then EEC in 1981, the Greek economy has undergone significant transformations that were followed by equivalent adjustments in labor legislation, in line with developments at the EU level. ${ }^{42}$ Labor market flexibilization was a key aim of the EU policies that were due to be implemented by the early 2000 s in order to address the challenges posed by globalization. ${ }^{43}$ However, these policies came at a cost for most workers. Even before the crisis, in 2007, $20 \%$ of the Greek workforce was receiving a monthly salary of less than $€_{700}{ }^{44}$ thereby creating a cheap, yet highly qualified labor force. Moreover, between 2003 and 2010, Greece ranked second in the list of countries with the highest rate of temporary employment in the EU. ${ }^{45}$ The social and political consequences of this phenomenon - that is, the ongoing social crisis they produced - fed into the dynamics that culminated in the so-called Greek Crisis. ${ }^{46}$

In order to understand the consolidation of contemporary labor relations in Greece, we have to focus on the intersection between global economic transformation, as manifested during the economic crisis, and the pre-already existing socio-economic contradictions and cultural specificities that characterize the Greek mode of micro-production. Given that "preceding concepts of social relations operate simultaneously alongside, or underneath capitalist systems",47 we should cease to think of changes in capital-labor relations as

41 See The Independent, http://www.independent.co.uk/news/business/news/brexit-guyhands-says-cut-wages-3o-percent-twenty-years-private-equity-a7540986.html (accessed 15 September 2019). Dedoussopoulos, A., V. Aranitou, F. Koutentakis and M. Maropoulou. Assessing the Impact of the Memoranda on Greek Labour Market and Labour Relations (Geneva: ILO, 2013). Ibid.

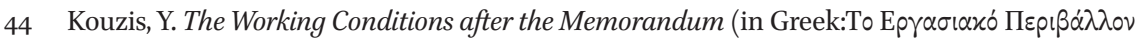

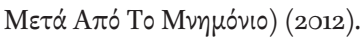

45 Pavlopoulos, D. Temporary Employment in Greece and in the EU: An Approach Using Longitudinal Data (in Greek) (Athens: Observatory of Social and Economic Developments. Labour Institute of the Greek General Confederation of Labour, 2015).

46 Dalakoglou, "The Crisis before 'The Crisis': Violence and Urban Neoliberalization in Athens 1."

Knight, Crisis and Prosperity: Status, Accountability and Time in Central Greece. 
produced by a crisis-induced "rupture", and focus instead on specifying local ways of doing capitalism.

In the context of Greece, where the tertiary economy is dominant, wage labor has always been short-term and precarious. The ostensible resistance of small-scale businesses to big capital's constant pressure, ${ }^{48}$ which apparently creates a distinct form of "Greek capitalism", is in fact sustained by undeclared wage labor, denials of salary payments, informality and refusal of basic labor rights. This condition is normalized through sociocultural elements such as the moralization of the informal-friendly relation between the capital owner and the worker, or the attribution of social status to certain jobs. Long before the crisis, the younger generations faced extremely uncertain living conditions, with the majority forced to invent additional types of informal work in order to make ends meet.

In the case of the public sector, there has indeed been a sort of rupture between the pre- and post-crisis eras. After the neoliberal restructuring of the public sector, the security that older generations enjoyed ceased to exist. The experience that younger people have of working in the public sector today is of ambiguous semi-public, semi-private contracts that last for five or eight months, and which do not even recognize them formally as workers. However, overall forms of intimidation and arbitrary actions based on patronage and informal structures of power are not the outcome of the crisis, but rather an enduring feature of everyday life in the Greek countryside.

In conclusion, perhaps the very fact that precarity has been the norm for many since long before the crisis, explains the majority of our respondents' difficulty in comprehending and perceiving the nature of the crisis.

\section{Acknowledgements}

This article was funded by the Institute of Societal Resilience of the Vrije Universiteit Amsterdam within the context of the project Precariat and from an Nwo, within the context of the Vidi project infra-demos.net. We would like to than both funders, the anonymous reviewers of the journal for their comments and our informants.

(C) Giorgos Poulimenakos, Anna Giulia Della Puppa, Antonios Alexandridis, Dimitris Pavlopoulos and Dimitris Dalakoglou, 2021. This is an open access article distributed under the terms of the CC BY 4.0 license.

48 Sakellaropoulos, Change in Social Stratification in the Greece of Crisis (2009-2017). 